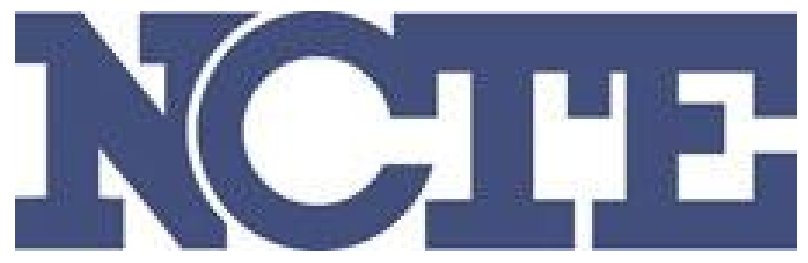

In Defense of the Liberal-Arts Approach to Technical Writing Author(s): Elizabeth Harris

Source: College English, Vol. 44, No. 6 (Oct., 1982), pp. 628-636

Published by: National Council of Teachers of English

Stable URL: http://www.jstor.org/stable/377282

Accessed: 09-08-2016 16:44 UTC

Your use of the JSTOR archive indicates your acceptance of the Terms \& Conditions of Use, available at

http://about.jstor.org/terms

JSTOR is a not-for-profit service that helps scholars, researchers, and students discover, use, and build upon a wide range of content in a trusted digital archive. We use information technology and tools to increase productivity and facilitate new forms of scholarship. For more information about JSTOR, please contact support@jstor.org.

National Council of Teachers of English is collaborating with JSTOR to digitize, preserve and extend access to College English 


\section{In Defense of the Liberal-Arts Approach to Technical Writing}

It may seem odd, and I think it should, that something called the liberal-arts approach to studying any language object needs to be defended. But in the academic area of technical writing, teachers and scholars have sometimes questioned the value of what has recently come to be called "the liberal-arts approach." By this term, "the liberal-arts approach" to technical writing, I mean any approach to research or scholarship in scientific and technological texts which employs concepts and methods primarily from the liberal arts: literary theory and history, traditional and modern rhetoric, linguistics, and the philosophy and history of science and technology. Suspicion about the value and appropriateness of such concepts and methods to the study and teaching of technical writing comes not only from within the field, but from outside it too. Just as some scholars and teachers of technical writing doubt that the liberal arts have anything to bring to it, so do some liberal-arts scholars-in particular, some literary scholars-doubt that technical writing belongs in the liberal arts.

I want to examine here the various arguments against the liberal-arts approach that are sometimes made from either side and to argue that this approachthough by no means the only valid one for studying technical writing-is both valid and essential. I maintain that we will neglect whole areas of the greatest interest and centrality to scientific, technological, and ordinary workaday writing if we divorce them from the liberal arts. In addition, not content to argue "'against," I want to suggest, in terms of one general model of discourse study, what various liberal-arts fields can bring to the study of scientific and technological texts.

I can identify three perspectives in technical writing from which the liberalarts approach may appear useless or suspect. I will call these the anti-academic, the pedagogical, and the social-science perspectives. Inevitably, these distinctions are somewhat artificial. Many individuals see the field from more than one perspective. And many individuals who see it from any of these perspectives

Elizabeth Harris received a bachelor of science degree in technical writing and editing from Carnegie-Mellon University and a PhD in English from Stanford. She is an assistant professor at the University of Texas at Austin and the author of several articles on technical writing and the rhetoric of scientific and technological texts. She is completing a book-length theoretical study of written scientific and technological discourses.

\section{College English, Volume 44, Number 6, October 1982}


may also appreciate the liberal-arts approach. I am concerned here not to classify individuals but to distinguish trends of thought in the field. ${ }^{1}$

From the anti-academic perspective, technical writing is uniquely "practical writing," and academic research, especially in the liberal arts, is impractical. For this perspective at its extreme, technical writing should be taught purely as a form of "language engineering", $-a$ technology itself. And what should be taught can be adequately determined by more or less casual contact with the practitioners of technical writing in the industrial, governmental, and research institutions where they work. There are disturbing implications and assumptions in this view, though it is, I think, understandable in terms of the history and some of the institutional circumstances of technical writing as an academic field. One implication of the anti-academic view is that the use of language to construct whole discourses in real situations can be taught by simple prescription and imitation. This misconception bespeaks ignorance of the complexity of the language object, its relation to the situation in which it is constructed, and the subjective experience of constructing it. While prescription and imitation have their uses in teaching, no one would openly suggest we teach any other kind of writing entirely by those techniques. ${ }^{3}$ The misconception that we can teach technical writing in these ways seems to derive from the most disturbing assumption of the anti-academic perspective: that we already know or will casually find out everything we need to know about technical writing in order to teach it. This assumption seems to me presumptuous and condescending. It presumes that everything useful to know about technical-writing texts is intuitively obvious. It suggests insensitivity to the variabilities and subtleties of all natural-language texts. It implies contempt for technical-writing texts.

At worse, the anti-academic position, within academe, is a vendetta. At best it was, I think, an early attempt to come to terms with the uncomfortable academic status of technical writing. As teachers and scholars in the field know, technical writing as a curricular area came into existence out of needs in the sciences and technologies which English departments either refused to meet or met reluctantly. The refusal was more than anti-scientistic spite, but expressed a longdeveloping tendency of English departments, especially in the post-World War II growth years, to throw off into new departments studies that were not strictly literary. ${ }^{4}$ Thus were created departments of linguistics, folklore, American

1. For a different view of the field, which distinguishes some of the same trends, see Paul V. Anderson, "The Need for Better Research in Technical Communication," in John A. Muller, ed., Proceedings: 31st Conference on College Composition and Communication: Technical Communication Sessions (n.p.: The Association of Teachers of Technical Writing; Department of Rhetoric, University of Minnesota; CCCC Special Committee on Technical Communication, 1980), pp. 2-13.

2. See John Wolfenden, "The Gap-and the Bridge," which casts writers metaphorically in the role of bridge-builders, in Phillipe Le Corbeiller, et al., The Languages of Science: A Survey of Techniques of Communication (New York: Basic Books, 1963), pp. 1-18.

3. Though Richard Ohmann does say that this suggestion is the implication of some freshman composition textbooks. See English in America (New York: Oxford University Press, 1976), pp. 133-171. 13.

4. See James Kinneavy, A Theory of Discourse (Englewood Cliffs, N.J.: Prentice Hall, 1971), p. 
studies, rhetoric and composition, and creative writing. Technical writing, where it did not find a home somewhere else entirely - in the College of Engineering or Communications or the Department of Rhetoric-became a despised stepchild, tolerated for its powerful connections elsewhere. As a new field technical writing also lacked an established tradition of research. Potentially the field embraced, as I shall indicate, several different traditions. In consequence, it could easily be detached from any tradition of academic research. And under the circumstances unreflective detachment from the traditions of academic research could become outright hostility to them. For the reasons I have indicated already, I think it is time to lay this sort of reactive thinking to rest. I do not argue that formal research is appropriate or possible in all institutions where technical writing is taught. I do argue that formal research is essential in the field generally.

But what kinds of research? The second of the perspectives I want to identify, the pedogogical perspective, holds that most of the unsolved problems in the field of technical writing concern how best to teach it. The implication of this approach is that research, where necessary at all, should be directed toward learning processes, curricular design, and teaching techniques. Many useful pedagogically-oriented studies and collections of studies recently have appeared. Among these I would include Donald Cunningham and Herman Estrin's The Teaching of Technical Writing (Urbana, Ill.: National Council of Teachers of English, 1975); Thomas Pearsall's Teaching Technical Writing: Methods for College English Teachers (Washington, D.C.: Society for Technical Communication, 1975); Thomas Sawyer's Technical and Professional Communication (Ann Arbor, Mich.: Professional Communication Press, 1977); and Merrill Whitburn's Teaching Technical Writing: The First Day in the Technical Writing Course (n.p., Association of Teachers of Technical Writing, 1979). Forthcoming of interest to graduate instruction is John Harris' Training of Technical Writing Teachers (also from ATTW). The Association of Teachers of Technical Writing has actively promoted pedagogical study through its publication of anthologies and the journal, The Technical Writing Teacher. The pedagogical approach to the field of technical writing has also been encouraged by circumstances. Recent demand for courses in discipline-specific, professional, and workaday writing has enlarged the field enormously with instructors who have no specialized background in it. Pedagogical research satisfies a real need in the field. And yet to pursue pedagogical research as the only concern of the field would be, again, to assume that we already know or will find out casually everything we need to know about the discourses of technical writing and the situations in which they are produced.

Some scholars who have wisely doubted this assumption have adopted research concepts and methods from the social sciences, conducting statistical and case studies among technical writers and readers. Statistical surveys among practitioners in the field have formalized and systematized our knowledge of their perceptions of it. Admirable examples of such surveys include Richard Davis' "How Important Is Technical Writing?-A Survey of the Opinions of Successful Engineers"' (The Technical Writing Teacher, 4 [1977], 83-88) and Paul 
Anderson's "Research Into the Amount, Importance, and Kinds of Writing Performed on the Job by Graduates of Seven University Departments that Send Students to Technical Writing Courses"' (paper presented at session on "Current Research in Technical Writing," MLA Convention, Houston, Texas, 29 Dec. 1980). Scholars using social-science concepts and methods have also researched the behavior of technical writers and readers: processes of composing, perceptions of readability and coherence, and social circumstances of writing. Forthcoming examples of studies in these areas include Linda Flower, John Hayes, and Heidi Swarts' "Revising Functional Documents: The Scenario Principle"; Dixie Goswami, Lee Odell, and Janice Redish's “Research About Writing: Some Practical Applications"; Jack Selzer's "What Constitutes a 'Readable' Technical Style?'; Thomas Huckin's "On Readability', Lester Faigley and Stephen Witte's "Topical Focus in Technical Writing"; and Charles Bazerman's "Scientific Writing as a Social Act." ${ }_{5}$

The social-science approach readily overlaps both the pedagogical and the liberal-arts approaches. For instance, both the Davis and Anderson surveys poll practitioners in the field to determine the content of technical writing courses. The Faigley and Witte study tests readers' perceptions of textual coherence to determine how writers of complicated texts should be taught to construct them. Psycholinguistic studies of textual features such as coherence may be regarded as social-science or as liberal-arts research, depending on whether they focus on the behavior of writers and readers in producing and perceiving these features or on the texts themselves. Research into the writing process often employs the concepts of generative grammar, which has tended to turn linguistics into an area of cognitive psychology, but studies of texts themselves, even employing the concepts of generative grammar, would seem to be most accurately regarded as liberal-arts studies. The fine distinctions do not matter much except that they help to further define the different approaches to research in the field. There is a more general conjunction between social-science and liberal-arts research, too, which I shall mention shortly.

The contribution of social-science research to technical writing, like the contribution of pedagogical research, is genuine. But to regard social-science research as the only appropriate research is also to make some questionable assumptions. The first of these is that we already know or can find out casually what to count or otherwise observe in technical-writing texts and in the processes by which they are generated and received. In fact when we examine surveys and case studies, we discover the degree to which, explicitly or implicitly, they depend on models of textuality that tell the researcher what to count or observe, and which are not necessarily obvious but have been highly developed in the literature of several fields. For instance, the Faigley and Witte study measuring readers' perceptions of certain kinds of textual coherence derives ultimately from the observation of Prague School linguists that texts have not only syntactic but topical structures that carry themes, or topics, throughout the

5. All in Paul Anderson et al., eds., New Essays in Technical and Scientific Communication (Baywood, N.J.: Baywood Press, 1982). 
texts. ${ }^{6}$ Research in technical writing using social-science concepts and methods will often depend on concepts and methods developed in liberal-arts disciplines, because the study of language texts has traditionally belonged to the liberal arts.

A further questionable assumption of a purely social-science approach to research in technical writing is that once we count or otherwise observe, we know all we need to about what we have counted or observed. In fact, when we examine surveys and case studies, we discover the frequency with which their findings require further interpretation. And this interpretation, like the decision about what to count or observe in the first place, may employ models of textuality from any of several liberal arts fields. For instance, the Davis survey discovered that $77 \%$ of its respondents thought a technical writing course should cover "[o]rganization of reports and other communications" (p. 86). But what is organization in natural-language discourse? Answers to this question come not only from the social-science fields of cognitive psychology and performance-oriented psycholinguistics, but from the liberal-arts fields of text-oriented linguistics, traditional and modern rhetoric, literary theory, and philosophy-as well as from the communications fields of information theory and media. Plainly, socialscience concepts and methods will be inadequate by themselves to deal with the language objects of technical writing.

Anti-academic, pedagogical, and social-science perspectives then are all inadequate by themselves in relation to the academic field of technical writing, though the pedagogical and social-science perspectives have important contributions to make. Before I go on to show more fully the contributions I think the liberal arts can make, consider the voices from within the liberal arts that object to making any contributions at all. In the perspective of some literary critics, technical writing is purely a form of "language engineering," and in teaching it we teach students merely to perform dull writing tasks mechanically and thereby to fit mindlessly into the institutions of industry and government. In this perspective, as in the anti-academic one within the field of technical writing itself, technical writing really offers nothing to study, except the scientific and technological subjects of its reference. Its language is merely a transparent medium, of no intrinsic account or interest, and therefore-presumably by contrast with the "language of thought" - it really can be taught merely by imitation and prescription. In this view such teaching, while necessary in the politics of educational institutions, is a betrayal of the mission of literary criticism, which is, in Matthew Arnold's famous words in "The Function of Criticism at the Present Time'?:

to know the best that is known and thought in the world and by, in its turn, making this known, to create a current of true and fresh ideas . . . to do this with inflexible honesty, with due ability; but ... to leave alone all questions of practical consequences and applications.

Literary criticism, however, is not all of literary study, let alone all of the

6. See F. Danes, ed., Papers on Functional Sentence Perspective (Prague: Academia, 1974); and P. Sgall, et al., Topic, Focus, and Generative Semantics (Kronberg: Scripton, 1973); as cited in Faigley and Witte's essay in the Anderson collection noted in footnote 5. 
study of natural-language texts. This larger study too has its mission to know and to create "a current of true and fresh ideas," even if those ideas do have practical consequences. The narrow literary perspective from which scientific and technological texts are considered no concern of liberal-arts scholars, like the anti-academic perspective in technical writing, expresses ignorance of the character of language objects in general and contempt for nonliterary language objects. The ignorance can be explained by the necessary limitation of scholarly education; the contempt perhaps by the understandable defensiveness of literary scholars in a culture which does not value literature as it should. The narrow perspective of some literary critics, however, is unworthy of the best. For language, as regarded by many linguists in this century, is, rather than a transparent medium for the presentation of previously formed thoughts, the means of thought. In the words of the pioneering linguist Wilhelm von Humboldt: "The interdependence of word and idea shows us clearly that languages are not actually means of representing a truth already known, but rather of discovering the previously unknown." 7 The interdependence of word and idea means that scientific and technological texts are themselves means of discovering the previously unknown. We may, as writers, think that we know what we are going to write, but we do not know exactly until the exact words of our text occur to us-which is why we do not accept from students the excuse that they knew what they wanted to say but they just didn't get it down. The functionalist view of language has added that all utterances are purposeful. The meaning of a technical report is thus inseparable from both its construction in certain words arranged in certain orders and from the function it embodies. Without the construction there is no meaning, only the writer's intention to construct some particular kind of meaning. And without the construction there is also no function, only the writer's hope to achieve one.

This unity of language objects means that texts of any size or complexity, as writing teachers know, can rarely be produced mechanically, and their production can rarely be taught prescriptively. As soon as we begin to prescribe organizational structures, for instance, we find that we must discuss their modification for different functions and for the embodiment of different kinds of ideas. For instance, the organization of a process description, which is a certain kind of idea-a temporal event-will nevertheless vary in its details according to whether the text reports or directs or demonstrates or does something else. Similarly the achievement of, say, the directive function in a process description will vary according to exactly how it is organized-what is put in, what is left out, how simultaneous actions are dealt with-and exactly what process the directions refer to. Indeed, I believe this is what most of us, in practice, try to teach our students: that many parts in a piece of writing depend on each other and on certain external circumstances. The unity of language objects means not only that they can rarely be produced mechanically but that what there is for liberal-

7. Werke, Vol. 3 (Darmstadt: Wissenschaftliche Buchgesellschaft, 1963), pp. 19-20; as cited in David E. Linge, ed. and tr., "Editor's Introduction," Hans-Georg Gadamer, Philosophical Hermeneutics (Berkeley: University of California Press, 1976), p. xxx. 
arts scholars to study in technical-writing texts is nothing less than the relations of meaning, structure, and function, as those are variously embodied in such texts. I do not see how anyone can doubt that such a study is worthy of the liberal-arts tradition.

A model of the language-communication process developed by American pragmatic philosophy provides one way of organizing the areas in which the liberal arts can contribute to the study of technical writing. Developed by C. S. Peirce and Charles Morris, this model posits that every act of language communication involves a sign, something the sign refers to, and some effect on an interpreter "in virtue of which the thing in question is a sign." ${ }^{8}$ We can therefore study language communication in three aspects: its signs, their relations to what they refer to, and their effects on their interpreters. The study of the constitution and formal relations of signs themselves, Morris terms syntactics. The study of signs' relations to their referents, he terms semantics. And the study of signs' effects on interpreters, he terms pragmatics (pp. 21-22). Morris is concerned with language rather than with whole texts, and his divisions of language study have become familiar in linguistics, but the rhetorical theorist James Kinneavy observes that we can also study whole texts in their syntactic, semantic, and pragmatic aspects.

To the study of each of these aspects of scientific and technological texts, the liberal-arts fields can make great contributions. Literary theory, rhetoric, and linguistics are all sources of concepts for approaching the syntactics of technical writing discourses-their formal constitution and internal relations. Literary theory has concerned itself with the formal characteristics of writing and speech, of monologue and dialogue, and of narration and description. (And there is a sense in which all scientific discourse and all highly conventionalized discourse-which includes much technological writing-are dialogic.) Traditional and modern rhetorics have concerned themselves with the formal characteristics induced in discourse by its embodiment of different logical processes, and by its temporal or spatial relations to extralinguistic reality. Rhetorics have also considered the formal coherence of sentences and paragraphs and the formal structures of style. Certain areas of linguistics too have concerned themselves with the coherence of sentences, paragraphs, and whole texts.

Literary theory and rhetoric, along with philosophy and the history of science and technology, also provide concepts for approaching the semantics of technical-writing discourses-their relations to their referents. Literary theory and rhetoric have, as I have already mentioned, concerned themselves with the differences among discourses with temporal and discourses with spatial relations to extralinguistic reality: that is, with narrative, process, descriptive, classificatory, and other relations to reality. In exploring the fictionality of literary referents, literary theory has also exposed the "fictionalities" of scholarly and scientific referents, the degree to which they are created by scholarly and scientific ways of understanding the world. The philosophy of science, particularly its

8. Charles Morris, Foundations of the Theory of Signs (Chicago, Ill.: University of Chicago Press, 1938); rpt. in Writings on The General Theory of Signs (The Hague: Mouton, 1971), p. 19. 
epistemology, has long concerned itself with how science knows. Since science exists in its discourses, the epistemology of science bears directly on how scientific discourses are related to their referents. The history of science and technology catalog the changing specifics of their knowing and doing-what Thomas Kuhn calls their changing paradigms. Finally, literary theory, functionalist linguistics, and, again, the philosophy of science and technology are rich sources of concepts for approaching the pragmatics of scientific and technological texts, that is their effects on readers. Literary theory has concerned itself with how effects on readers-and in a sense even readers themselves-are embodied in texts. Functionalist linguistics has considered the various functions of all language, including those of scientific and technological language. And the philosophy of science has concerned itself specifically with the functions of language in science and technology.

Studies of scientific and technological texts have for years taken the liberalarts approach-or at this point I should say one of the many liberal-arts approaches. Many of these studies have so far, except for a rare citation, no part in the academic field of technical writing. I argue that they belong to what should become its liberal-arts research tradition as surely as studies produced by scholars identified with the field. ${ }^{9}$ Some studies identified with technical writing, however, have also taken the liberal-arts approach. Recent and forthcoming studies bringing rhetorical, literary, historical, and philosophical concepts to bear on technical-writing texts include some essays in the Muller collection cited in footnote 1: Douglas Catron's "Rhetoric and the 'Art' of Technical Writing," Michael Halloran's "Toward a Rhetoric of Scientific Revolution," Michael Marcuse's "Ethos in Technical Discourse: The Current State of the Question," Carolyn Miller's "The Ethos of Science and the Ethos of Technology," Larry Reynold's "Intimations of Character in Technical Jargon," and Arthur Walzer's "Ethos in Technical Writing." To these essays should be added Michael Connaughton's "Notes Towards a History of American Scientific Writing," David Dobrin's "What Does 'Objectivity' in Technical Writing Do?"' and Debra Journet's "The Rhetoric of Scientific Writing"; ${ }^{10}$ James Paradis' "Historical Aspects of Language Reform in the Sciences," James Stephens' "Style as Therapy in

9. A few examples are: Leonard Bloomfield, Linguistic Aspects of Science (Chicago: University of Chicago Press, 1939); rpt. in Otto Neurath, et al., eds., International Encyclopedia of Unified Science Vol. 1, No. 4 (Chicago: University of Chicago Press, 1939); P. W. Bridgman, "The Operational Aspect of Meaning," Synesthese, 8 (1950-1951), 251-259; Ernst Cassirer, An Essay on Man (New Haven, Ct.: Yale University Press, 1944), Chapter 11; Roland Barthes, "Science versus Literature," in Michael Lane, ed., Introduction to Structuralism (New York: Basic Books, 1970), pp. 410-416; F. G. Crookshank, "The Importance of a Theory of Signs and a Critique of Language in the Study of Medicine," in C. K. Ogden and I. A. Richards, The Meaning of Meaning (New York: Harcourt Brace, 1944), pp. 337-355; Stanley Gerr, "Language and Science: The Rational, Functional Language of Science and Technology," Philosophy of Science, 9 (1942), 146-161; Myrna Gopnik, Linguistic Structures in Scientific Texts (The Hague: Mouton, 1972); Charles Sanders Peirce, "Ideas, Stray or Stolen, about Scientific Writing, No. 1 (An Unpublished Manuscript)," Philosophy and Rhetoric, 11 (1978), 147-155; and W. V. Quine, "The Scope and Language of Science," The British Journal for the Philosophy of Science, 8 (1957-58), 1-17.

10. All presented at a session on "Humanistic Approaches to Technical Communication," MLA Convention, New York, December 29, 1981. 
Renaissance Science," and James Zappen's "A Rhetoric for Science and Engineering," all in Anderson's collection cited in footnote 5; and my own "Applications of Kinneavy's Theory of Discourse to Technical Writing," "A Theoretical Perspective on 'How To' Discourse," and "Language and History in Science and Technology." ${ }_{11} \mathrm{~A}$ wealth of possibilities for the liberal-arts approach remains.

Are such studies useful in teaching introductory courses in technical writing? I think many of them are, although not always directly; they are mostly not the sort of reading we assign to undergraduates. But then no one expects the physicist or the literary critic to apply all of contemporary research in the field to teaching an introductory course in physics or literature. The value of liberal-arts research in scientific and technological texts generally seems to me to deepen and widen our own understanding of their past and present formal characters, meanings, and functions. We teach all of these matters, under some guise, in the introductory technical writing course. The more we know about them in general, or so it would seem, the better able we are to deal with the concrete, unique situations that arise when we talk to students about their own writing. "Why does this report have a persuasive rather than an objective tone?" "Is science really objective?" "What is the difference between persuasion and demonstration?" "Can't they sometimes be organized the same?" These are all questions that may reasonably occur in introductory classes and in conferences with beginning students, and all are questions illuminated by studies cited in the preceding paragraph.

11. In, respectively, College English, 40 (1979), 625-32; Anderson, et al., New' Essays; and "Humanistic Approaches to Technical Communication." 